\title{
MANAGEMENT OF CHILD INJURIES IN TRAFFIC AND OTHER ACCIDENTS: THE WHO POLICY GUIDELINES
}

\section{URAZY U DZIECI W ZDARZENIACH DROGOWYCH I INNYCH WYPADKACH: WYTYCZNE WHO}

\author{
Krzysztof Goniewicz ${ }^{1,2(A, B, C, D, E, F)}$, Mariusz Goniewicz ${ }^{3(B, C, D, E)}$, \\ Witold Pawłowski ${ }^{1(C, D)}$, Piotr Fiedor ${ }^{4(D, E)}$ \\ ${ }^{1}$ Department of Disaster Medicine, Medical University of Warsaw, Poland \\ ${ }^{2}$ Department of Security Studies, Polish Air Force Academy, Poland \\ ${ }^{3}$ Department of Emergency Medicine, Medical University of Lublin, Poland \\ ${ }^{4}$ Department of General and Transplantation Surgery, Medical University of Warsaw, Poland
}

Authors' contribution

Wkład autorów:

A. Study design/planning

zaplanowanie badań

B. Data collection/entry

zebranie danych

C. Data analysis/statistics

dane - analiza i statystyki

D. Data interpretation

interpretacja danych

E. Preparation of manuscript

przygotowanie artykułu

F. Literature analysis/search

wyszukiwanie i analiza literatury

G. Funds collection

zebranie funduszy

Tables: 1

Figures: 1

References: 20

Submitted: 2016 Dec 04

Accepted: 2017 March 02

\section{Summary}

Children injuries are one of the biggest problems in modern medicine that require vigorous and preventive actions. All kinds of injuries resulting from road accidents are the most common cause of death in children, more common than cancer and birth defects. In the years 1995-2009, there were 113211 accidents involving 959 children aged 0-14 years in Poland in which 3791 children died and 117730 were injured. Most fatalities were recorded in children in the age range 7-14 years. The following study presents the main problems of road safety and the nature, causes and consequences of injures in children in Poland and worldwide. It discusses the risks associated with children involved in traffic as well as ways of reducing the number of accidents in children based on the WHO report.

Keywords: injuries, children, accidents

\section{Streszczenie}

Urazy i ich następstwa u dzieci są jednym z największych problemów współczesnej medycyny, które wymagają działań energicznych i zapobiegawczych. Obrażenia spowodowane wypadkami drogowymi są najczęstszą przyczyną zgonów wśród dzieci, częstszą niż choroby nowotworowe i wady wrodzone. W Polsce w latach 1995-2009 doszło do 113211 wypadków drogowych z udziałem dzieci w wieku 0-14 lat. 3791 dzieci zmarło, a 117730 zostało rannych. Większość ofiar śmiertelnych odnotowano wśród dzieci w wieku 7-14 lat. Praca przedstawia główne problemy związane z bezpieczeństwem ruchu drogowego, charakter, przyczyny i konsekwencje wypadków drogowych wśród dzieci w Polsce i na świecie. Omówione w niej zostały także zagrożenia związane z udziałem dzieci w ruchu drogowym, jak również sposoby na zmniejszenie liczby wypadków wśród dzieci na podstawie raportu WHO.

Słowa kluczowe: obrażenia, dzieci, wypadki

\section{Introduction}

According to the WHO, each year about 75 million people suffer from injuries in the world, and $23 \%$ of trauma victims die or suffer permanent injury. Such a large number of injuries is due to, inter alia, changes in the pattern of life, transformation of economic systems, developments in the automotive industry and mechanisation of agriculture. Further, there are noticeable a constant pursuit of work, wish to move from place to place, insufficient rest, violation of road safety rules, poor quality of road infrastructure and poor technical condition of vehicles. Many of the threats facing the contemporary world also concern the children to a large extent. Injuries in children older than 2 years are the cause of more deaths than all other childhood diseases combined. More than $20 \%$ of the population experience trauma, and about $10 \%$ of accidents cause some sort of disability in children. Further, road injuries are among the predominant causes of deaths. Falls from height, drowning, burns, beatings and the use of physical violence (i.e. child abuse) are rarely causes of injuries. The damage resulting from traffic accidents is the leading cause of death among children, more frequent than cancer and birth defects. As the WHO report of 2007 - "Youth and road safety" - shows, road accidents are the leading

Goniewicz K, Goniewicz M, Pawłowski W, Fiedor P. Management of child injuries in traffic and other accidents: the WHO policy guidelines. Health Prob Civil. 2018; 12(3): 157-162. https://doi.org/10.5114/hpc.2018.76516

Address for correspondence / Adres korespondencyjny: Krzysztof Goniewicz, Department of Disaster Medicine, Medical University of Warsaw, Żwirki i Wigury 81 A, 02-01 Warsaw, Poland, e-mail: krzysztof.goniewicz@wum.edu.pl, phone: +48225720545

Copyright: (C) Pope John Paul II State School of Higher Education in Biała Podlaska, Krzysztof Goniewicz, Mariusz Goniewicz, Witold Pawłowski, Piotr Fiedor. This is an Open Access journal, all articles are distributed under the terms of the Creative Commons Attribution-NonCommercial-ShareAlike 4.0 International (CC BY-NCSA 4.0) License (http://creativecommons.org/licenses/by-nc-sa/4.0/), allowing third parties to copy and redistribute the material in any medium or format and to remix, transform, and build upon the material, provided the original work is properly cited and states its license. 
cause of death among young people. According to the WHO, about 400000 people under 25 years are killed in road accidents each year, and millions suffer from various injuries $[1,2,3,4]$.

Currently, a fatal road accident occurs on average every 50 seconds in the world, and every two seconds it causes damage in humans. As a result of injuries sustained in road accidents, mortality is $2.2 \%$ of all deaths worldwide. Road accidents cause more deaths than wars, and millions of people become handicapped. The economic consequences of such a large number of fatal accidents and injuries leading to disability are significant. In many countries, low-and middle-income costs of road accidents consume $1.5-2 \%$ of gross domestic product, and some exceed the value of international aid [5,6,7].

Injury and violence is a major cause of fatality resulting in about 950,000 deaths in children and young people under the age of 18 years each year. Unintentional injury (road traffic collision, drowning, burn, falls and poisoning) account for about $60 \%$ of all child deaths in the world. Other unintentional injuries (smothering, asphyxiation, choking, animal and snakebites, hypothermia and hyperthermia) account for $23 \%$ of childhood deaths. It is well known that children in poorer countries and those from poorer families are the most vulnerable. The rate of child injury death is 3.4 times higher in low-income and middle-income than in highincome countries. The child-injury pyramid showed that, for each child under 19 years who was fatally injured, 45 children required hospitalisation and further 1,300 needed medical care at outpatient emergency clinics. A non-fatal injury not only causes suffering but also constitutes a financial burden for the health care system. It is also worth noting that $50 \%$ of those under 12 years who were treated in emergency departments remained with some form of disabilities (physical, mental, sociological), which has an impact on their lives as well as members of their families and the society. It is due to their inability to attend school, find suitable work or engage in an active social life.

Since children are not small adults they have different physical and cognitive abilities. They are curious and ready to experiment. They can be exposed to injury risk at different age in different countries while entering the formal workplace. Also some legal aspect connected with driving a car or drinking alcohol may influence the problem. For example, alcohol can be legally consumed at the age of 15 in Belgium, 20 in New Zealand; a car can be legally driven in New Zealand at the age of 15, and 18 in Sweden. A small stature is another factor making children particularly vulnerable to injury; they are less visible than adults and when hit by a vehicle, they are more likely to get a head or neck injury. Since they have smaller airways, they are particularly susceptible to aspiration than adults. Their skin is thinner, so they get deeper burns more quickly, even at lower temperature. In children below 15 years, a fatality rate is $24 \%$ higher in boys than in girls due to the fact that boys behave more impulsively, demonstrate higher activity levels and engage in more risky behaviour. There are certain socioeconomic factors associated with the risk of injury in children such as economic factors (family income), social factors (maternal education), family structure (single parenting, maternal age, number of occupants of the household, number of children), accommodation (type of tenancy, housing, overcrowding) and access to high quality medical services that can influence not only the likelihood of survival but also its long-term consequences. The studies conducted in the centres involved in the biomechanics of transportation and injury show that the risk of injury and the effects of impact increase proportionally to velocity. Body overload in the moment of vehicle collision impact is so great that the passenger's weight of increases a few or even several times. At a speed of $50 \mathrm{~km} / \mathrm{h}$, the collision effects are the same as when a body falls from a height of 10 feet (3 floors). At the speed of $80 \mathrm{~km} / \mathrm{h}$, it corresponds to the weight dropped from a height of 24 meters (8 floor). At a speed of $100 \mathrm{~km} / \mathrm{h}$, the collision effects are the same as when a body falls from a height of 40 meters (12-13 floor). A person weighing $90 \mathrm{~kg}$, driving with unfastened seatbelts, in a collision at $50 \mathrm{~km} / \mathrm{hr}$. hits the windshield with the force of the concrete block weighing 3.5 tons $[8,9,10]$.

Another threat to the Polish roads are young drivers (18-25 years). According to the Police Headquarters data, young drivers in Poland are the perpetrators of $18 \%$ of all accidents in which $18 \%$ of those involved die. The causes of excessive risk associated with the involvement of young people in traffic are a lack of experience and driving skills, willingness to take risky behaviours, driving in times and places of particular risk (night time, weekends) and driving under the influence of alcohol. Young people are confident of their abilities, i.e. receiving and processing stimuli. However, being too inexperienced, they do not leave any margin for error. A young driver is the most reasonable when driving alone. With an increasing number of friends, the chances for survival decrease. If a teenager takes one person, the chances of their safe arrival fall by $39 \%$. When driving with two people, the risk doubles. Recklessness occurs in the presence of peers. It causes that s/he desires to impress others and show that $\mathrm{s} /$ he can control speed $[6,11,12]$. 


\section{Aim of the study}

The need for preventive measures to reduce the number of road accidents is indisputable and yet, at present, it seems impossible to eliminate road accidents entirely. Therefore, whole communities and those in charge of rescue systems should focus their attention on increasing the chances of saving lives on the site of road accidents to reduce the number of fatalities or limit the extent of post-traumatic disabilities.

There are three cooperating institutions on the site of a road accident that are responsible for pre-hospital activities in the Polish rescue system. These include medical units (medical rescue teams), the Fire Brigade units and the Police. Effective work of the rescue system should be based on integration and close cooperation of all services involved in the rescue action, which guarantees unfailing functioning of all links of the so called "survival chain".

Proper coordination of the activities on the site of a road accident is possible due to regular training including the specificity of tasks of every service and the possibility of cooperation in emergency situations.

The above mentioned services undertake professional actions on road accident sites. However, each of the services has own separate guidelines, most often following narrow specialist proceedings, which results in an inefficient use of all rescue possibilities. The aim of this training is to increase the quality and efficiency of rescue activities based on the guidelines involving cooperation, understanding and completion among all the rescue services on the road accident sites. This programme is dedicated to those who are responsible for the organisation and coordination of actions in such situations as road accidents, and those responsible for the programmes aimed at increasing professional qualifications. In assessing this programme, we followed the general guidelines outlined by the World Health Organisation $[13,14,15]$, Polish legal regulations $[16,17]$ and the analyses of the WHO project entitled „Improving rescue services activities in different types of accidents”, which has been run in Poland as a 5-year strategy of improving road traffic safety.

Since each child has the right to live in a safe environment and be protected from injury and violence, there are many issues to resolve in order to prevent child injury. It is also a matter of global improvement of child health by involving the issues into child health strategies and child survival programmes that should include legislation, regulation and their enforcement; product modification; environmental modification; supportive home visit; the promotion of safety devices as well as education and teaching of skills.

Common child injury prevention strategies suggested for five major unintentional injuries (traffic, drowning, burns, falls, poisoning) are listed in Table 1.

Table 1. Key approaches to addressing child injuries

\begin{tabular}{|c|c|c|c|c|c|}
\hline Key approaches & Traffic & Drowning & Burns & Falls & Poisoning \\
\hline $\begin{array}{l}\text { Legislation regula- } \\
\text { tions, and } \\
\text { enforcement }\end{array}$ & $\begin{array}{l}\text { Speed limits; } \\
\text { comprehensive } \\
\text { drink-driving } \\
\text { laws, child restra- } \\
\text { ints laws }\end{array}$ & $\begin{array}{l}\text { Four-sided pool } \\
\text { fencing }\end{array}$ & $\begin{array}{l}\text { Hot water tap tem- } \\
\text { perature; legisla- } \\
\text { tion; } \\
\text { smoke alarms }\end{array}$ & $\begin{array}{l}\text { Playground equip- } \\
\text { ment standards }\end{array}$ & $\begin{array}{l}\text { Manufacture, stor- } \\
\text { age and distribu- } \\
\text { tion of harmful } \\
\text { substances requir- } \\
\text { ing safe } \\
\text { packaging }\end{array}$ \\
\hline $\begin{array}{l}\text { Product modifica- } \\
\text { tion }\end{array}$ & $\begin{array}{c}\text { Vehicle-front } \\
\text { Modification, child } \\
\text { restraint systems }\end{array}$ & $\begin{array}{c}\text { Personal flotation } \\
\text { devices }\end{array}$ & $\begin{array}{c}\text { Non-tip lanterns } \\
\text { and candle holders }\end{array}$ & $\begin{array}{l}\text { Baby walker } \\
\text { modification; } \\
\text { safety glass }\end{array}$ & $\begin{array}{l}\text { Medication pack- } \\
\quad \text { aging; child } \\
\text { resistant closures }\end{array}$ \\
\hline $\begin{array}{l}\text { Environmental } \\
\text { modification }\end{array}$ & $\begin{array}{l}\text { Child friendly in- } \\
\text { frastructure; safer } \\
\text { routes to school; } \\
\text { safer play spaces }\end{array}$ & $\begin{array}{l}\text { Barriers: cover- } \\
\text { ings and fencing }\end{array}$ & $\begin{array}{c}\text { Separation of } \\
\text { cooking area from } \\
\text { living area }\end{array}$ & $\begin{array}{l}\text { Window guards } \\
\text { on tall buildings, } \\
\text { roof railings, non- } \\
\text { climbable } \\
\text { banisters }\end{array}$ & $\begin{array}{l}\text { Safe storage of po- } \\
\text { tentially harmful } \\
\text { substances }\end{array}$ \\
\hline $\begin{array}{c}\text { Education and } \\
\text { skills development }\end{array}$ & $\begin{array}{l}\text { Helmet wear- } \\
\text { ing; using child } \\
\text { restraints }\end{array}$ & $\begin{array}{l}\text { Swimming train- } \\
\text { ing and supervi- } \\
\text { sion }\end{array}$ & $\begin{array}{l}\text { First aid - "cool } \\
\text { the burn" }\end{array}$ & $\begin{array}{l}\text { Supportive home } \\
\text { visitation to } \\
\text { identify fall } \\
\text { hazards }\end{array}$ & $\begin{array}{l}\text { Immediate first } \\
\text { aid }\end{array}$ \\
\hline $\begin{array}{l}\text { Emergency medi- } \\
\text { cal care }\end{array}$ & $\begin{array}{l}\text { Child-sized } \\
\text { equipment; child- } \\
\text { friendly environ- } \\
\text { ment }\end{array}$ & $\begin{array}{l}\text { Immediate resus- } \\
\text { citation }\end{array}$ & Burns centres & $\begin{array}{l}\text { Appropriate pae- } \\
\text { diatric acute care }\end{array}$ & $\begin{array}{l}\text { Poison control } \\
\text { centres }\end{array}$ \\
\hline
\end{tabular}

Source: World report on child injury prevention, the WHO, Geneva 2008, p. 166. 
Each of these approaches should be implemented based on the countries characteristics and abilities.

According to the WHO rapport, there are three phases of child injury prevention. These include:

A. Primary prevention: preventing a new injury,

B. Secondary prevention: reducing the severity of injuries,

C. Tertiary: decreasing the frequency and severity of disability after an injury.

It is worth pointing out that the cost of primary prevention programmes within a public health strategy of the country is much cheaper that any kind of prolonged treatment and care a child might need as a result of injury, e.g. it has been estimated that for each 1 US dollar spend on a child car seat, savings in direct and indirect health care cost and other costs to society amount to 29 US dollars. Besides, it should not be forgotten how many lives are saved as well.

In order to prevent an unintentional injury, one has to consider three aspects: education, enforcement and engineering. The first step in preventing injuries is legislation in the area of:

- road environment (child passenger restrains, seat-belts, bicycle helmet, motorcycle helmet),

- home environment (smoke alarms, hot water temperature legislation, child resistant containers),

- leisure environment (isolation and fencing of swimming pools).

A public health model that combines four area of injury prevention shows a holistic approach to the issue of child injury. In this model, different national and local agencies as well as organisation can work together to achieve the goal.

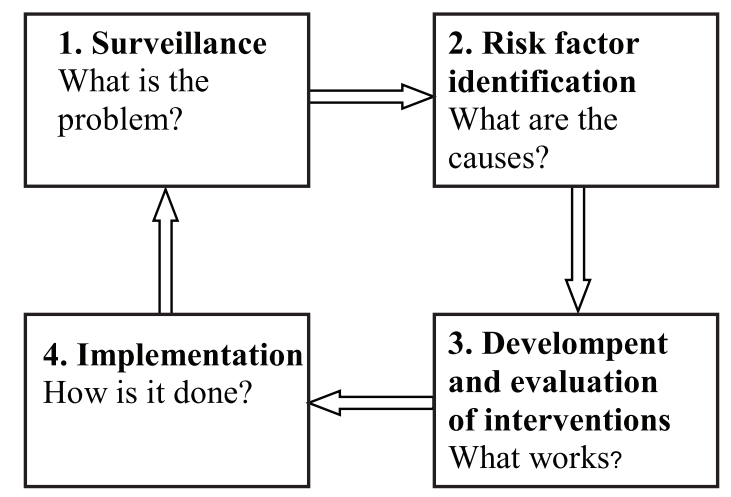

Figure 1. Public health approach to injury prevention Source: World report on child injury prevention, the WHO, Geneva 2008, p.31

To achieve the goal, governments, nongovernmental organisations, academic institutions, international agencies, media, teachers and community leaders, parents and the business sector should work together. The public health sector plays a major role in the process and should be responsible for:

Collecting and analysing data, caring out research on risk factors; implementing, monitoring and evaluating interventions; delivering appropriate primary, secondary and tertiary care and campaigning for greater attention to the issue of child injuries.

Basing on the WHO report findings, each country should start developing child injury prevention programmers which would follow seven general recommendations.

1. Integrate child injury into a comprehensive approach to child health and development: a child injury prevention programmes should be part of generally recognised child health service;

2. Develop and implement a child injury prevention policy and a plan of action: each county should prepare its own programme including agencies responsible for transport, health, planning, consumer product safety, agriculture, education and law;

3. Implement specific actions to prevent and control child injuries: the list of the proposed interventions is included in Table 1;

4. Strengthen health system to address child injuries: special emphasis should be placed on efficient system of pre-hospital care, child-specific equipment and drugs to manage a small patient, rehabilitation programmes (physical and psychological), coordination in delivering holistic care;

5. Enhance the quality and quantity of data for child injury prevention, i.e. the system on child injuries should be simple and cost effective, understandable for the staff that uses it, calibrated in accordance with national and international standards;

6. Define priorities for research and support research on the causes, consequences, cost and prevention of child injuries; it should involve an economic analysis, intervention trials, information on the fate of the children who survived, and implementing the idea of prevention into child health programmes; 
7. Raise awareness of and target investments towards child injury prevention by letting well-known people and political leaders campaign for child injury prevention and introducing these ideas into school and university curricula.

Children are not "little adults." Their different anatomical structure, maturity, variety of interests, need for fun and safe passage to school mean that children require special security measures. The ways of reducing the risk of children in road traffic include, inter alia, setting a good example of compliance with traffic rules by adults, providing adequate care to the youngest children (especially during the holidays), prohibiting the play in the nearby roads or creating safe playgrounds. Further, the child should be woken early enough not to hurry to school, dressed in bright clothes, especially during autumn and winter, supplied with reflectors (reflective elements secured in a child is visible from a distance, giving the driver time to reduce the car's speed and adequate pedestrian evade), leaving a self-ban on the way for children under the age of 12 years (cycling). Besides, collision-free cycle paths (especially in cities) should be developed and cyclists obliged to equip the bike with lights and reflective elements. Finally, cyclists and motorcyclists should wear helmets, those driving cars should fasten seat belts even on the shortest route and children are to be safely placed in child safety seats $[5,8,18,19,20]$.

A programme on transportation and moving around can play a major role in reducing the number of injuries. Accordingly, such a programme is an investment in the future. By introducing it, one can educate not only wellbehaved and safe future drivers, but above all informed citizens who exhibit appropriate values, understand others' needs, not necessarily in traffic.

\section{Conclusions}

It is essential to accept the fact that an injury is not the result of random, uncontrolled factors (although many people may think so). Injuries are preventable! France sets a good example with a 34\% reduction in road traffic deaths as a result of introducing speed reduction, traffic calming, control of drinking and driving and increased seats-belts use between 2002-2004. It is the public health responsibility to collect data, analyse risk factors, intervene, or implement some proven prevention method s (for example: speed reduction, traffic calming, control of drinking and driving, etc.). Injury as an issue to be solved and should be discussed on a global but also national and local level. Each country should develop its own action plan involving different bodies and agencies (non-governmental organisations, academic institutions and industry). Preventing child injury is also very cost effective from an economic perspective of each country. It is also absolutely necessary to understand that unless injury prevention is included in health care programmes for children, the impact of the large investment in immunisation, nutrition and maternal care may be lost due to number of unintentional injuries or deaths. Having that information in mind, one might hope that necessary activities mentioned above may be taken and, as a result, the number of killed or injured children decreased each year in the world.

\section{References:}

1. Viner RM, Ozer EM, Denny S, Marmot M, Resnick M, Fatusi A, et al. Adolescence and the social determinants of health. The Lancet. 2012; 379(9826): 1641-1652. https://doi.org/10.1016/S0140-6736(12)60149-4

2. Peden MM. World report on child injury prevention. Geneva: World Health Organization; 2008.

3. Viner RM, Coffey C, Mathers C, Bloem P, Costello A, Santelli J, et al. 50-year mortality trends in children and young people: a study of 50 low-income, middle-income, and high-income countries. The Lancet. 2011; 377(9772): 1162-1174. https://doi.org/10.1016/S0140-6736(11)60106-2

4. Sleet DA, Ballesteros MF, Borse NA. A review of unintentional injuries in adolescents. Annual Review Of Public Health. 2010; 31: 195-212. https://doi.org/10.1146/annurev.publhealth.012809.103616

5. Brussoni M, Olsen LL, Pike I, Sleet DA. Risky play and children's safety: Balancing priorities for optimal child development. International Journal of Environmental Research and Public Health. 2012; 9(9): 3134-3148. https://doi.org/10.3390/ijerph9093134

6. Borgman MA, Maegele M, Wade CE, Blackbourne LH, Spinella PC. Pediatric trauma BIG score: predicting mortality in children after military and civilian trauma. Pediatrics. 2011; 127(4): e892-e897. https://doi.org/10.1542/peds.2010-2439

7. Goniewicz K, Goniewicz M, Pawłowski W, Fiedor P, Lasota D. Risk of road traffic accidents in children. Medical Studies. 2017; 33(2): 155-160. https://doi.org/10.5114/ms.2017.68712

8. Little H, Shirley W. Individual differences in children's risk perception and appraisals in outdoor play environments. International Journal of Early Years Education. 2010; 18(4): 297-313.

https://doi.org/10.1080/09669760.2010.531600 
9. Desapriya E, Sones M, Ramanzin T, Weinstein S, Scime G, Pike I. Injury prevention in child death review: child pedestrian fatalities. Injury prevention. 2011; 17(Suppl. I): i4-i9. http://dx.doi.org/10.1136/ip.2010.026914

10. Peden M. World report on child injury prevention appeals to "Keep Kids Safe". Injury Prevention. 2008; 14(6): 413-414. https://doi.org/10.1136/ip.2008.020693

11. The Police Headquater's road accidents statistics. Available from: http://statystyka.policja.pl/st/ruchdrogowy/76562,Wypadki-drogowe-raporty-roczne.html

12. Goniewicz K, Goniewicz M, Pawłowski W, Fiedor P. Road accident rates: strategies and programmes for improving road traffic safety. European Journal Of Trauma And Emergency Surgery. 2016; 42(4): $433-438$. https://doi.org/10.1007/s00068-015-0544-6

13. Mock C, Quansah R, Krishnan R, Arreola-Risa C, Rivara F. Strengthening the prevention and care of injuries worldwide. The Lancet. 2004; 363(9427): 2172-2179. https://doi.org/10.1016/S0140-6736(04)16510-0

14. Katz SH, Falk J. Misplaced endotracheal tubes by paramedics in an urban emergency medical services system. Annals Of Emergency Medicine 2001; 37(1): 32-37. https://doi.org/10.1067/mem.2001.112098

15. Sasser S, et al. Prehospital trauma care systems. Geneva: World Health Organization; 2005.

16. Ustawa z dnia 20 czerwca 1997 r. - Prawo o ruchu drogowym. (in Polish)

17. Ustawa z dnia 8 września 2006 r. o Państwowym Ratownictwie Medycznym (in Polish).

18. Dworkin PH. Pediatria. Wrocław: Wydawnictwo Urban \&Partner; 2000 (in Polish).

19. Farmer PE, Kim JY. Surgery and global health: a view from beyond the OR. World Journal Of Surgery. 2008; 32(4): 533-536. https://doi.org/10.1007/s00268-008-9525-9

20. Pless I, Hagel B. Injury prevention: a glossary of terms. Journal Of Epidemiology And Community Health. 2005; 59(3): 182. http://dx.doi.org/10.1136/jech.2003.017715 